\title{
Kearifan Lokal dalam Membentuk Daya Pangan Lokal Komunitas Molamahu Pulubala Gorontalo
}

\begin{abstract}
Amir Fadhilah ${ }^{1}$
Abstrak

Perspektif budaya memandang makanan bukanlah sesuatu yang dipandang semata-mata berhubungan dengan aspek fisiologis dan biologis manusia melainkan secara menyeluruh terserap dalam suatu sistem budaya pangan. Sistem budaya pangan (makanan) mencakup kegiatan produksi, distribusi, dan konsumsi makanan yang di dalamnya tersirat pemenuhan kebutuhan manusia- -primer, sosial, dan budaya dalam rangka melangsungkan kehidupan dan meningkatkan kesejahteraan diri, keluarga, dan masyarakatnya. Tradisi kuliner berbasis pangan lokal merupakan bentuk kearifan local sebagai gambaran pola-pola hidup masyarakat yang mampu menghadirkan identitas kolektivitas dan representasi sosial budaya dalam mengkonsepkan makanan, fungsi sosial makanan.
\end{abstract}

Kata Kunci : budaya pangan, kearifan lokal, pangan lokal

\section{Abstract}

The persepective of culture considers food not only as a physicological and biologial aspect of human but also includes it in a food culture system. Food culture system includes how food is produced, distributed and consumed. It also implicitly tells how the people tries to fulfill their need of food, social and cultural aspect in order to preserve their life, as a family and society. The culinary tradition which based on local food is a form of local genius as a description of how people lives in many patterns. These patterns present collective identity in concepting food as social funcion.

Keywords : food culture, local genius, local food

\footnotetext{
${ }^{1}$ Fakultas Adab dan Humaniora \& Fakultas Ilmu Tarbiyah dan Pendidikan Universitas Islam Negeri (UIN) Syarif Hidayatullah Jakarta
} 


\section{A. Pendahuluan}

Lingkungan sosial memberikan gambaran jelas tentang perbedaan pola makan. Setiap masyarakat atau suku mempunyai kebiasaan makan berbeda sesuai kebiasaan yang dianut.. Kebutuhan makan bukanlah satu-satunya dorongan untuk mengatasi rasa lapar, di samping itu ada kebutuhan fisiologis, seperti pemenuhan gizi ikut mempengaruhi. Setiap strata atau kelompok sosial masyarakat mempunyai pola tersendiri dalam memperoleh, menggunakan, dan menilai makanan yang merupakan ciri dari strata atau kelompok sosial masing-masing ${ }^{2}$. Hal ini menyebabkan semakin beragam konsumsi jenis makanan pokok.

Komunitas-komunitas di Indonesia telah mengembangkan berbagai makanan pokok seperti sagu, jagung, ketela pohon, dan ubi jalar. Berbagai jenis tanaman itu tumbuh dan tersedia sepanjang tahun di berbagai keadaan lahan dan musim. Sejak dulu secara turun-temurun masyarakat desa terbiasa memanfaatkan sumber-sumber pangan yang beragam itu sebagai basis pemenuhan kebutuhan pangan pokok seharihari maupun sebagai camilan. Keragaman pangan juga mengandung keragaman nutrisi, bahkan diantara tanaman pangan itu berkhasiat obat. Sistem pangan lokal inilah yang menjadi andalan untuk menjamin pemenuhan kebutuhan pangan dan mengatasi ancaman dari bahaya kelaparan atau krisis pangan ${ }^{3}$. Berbagai potensi yang terkandung dalam sistem pangan lokal inilah yang sangat mungkin dapat mengatasi persoalan pangan pada

\footnotetext{
2 Suhardjo. 1989. Sosio Budaya Gizi. Departemen Pendidikan dan Kebudayaan, Direktorat Jenderal Pendidikan Tinggi, dan Pusat Antar Universitas Pangan dan Gizi IPB, Bogor
}

3 Witoro, 2003, Menemukan kembali dan Memperkuat Sistem Pangan Lokal, Makalah Lokakarya Forum Pendamping Petani Regio Gedepahala, Kampung Pending, Sukabum, 2-24 September 2003 tingkat komunitas. "communitybased food systems" memiliki peran penting dalam menjamin pemenuhan kebutuhan pangan. Community-based food system menawarkan kepada rakyat suatu peluang di mana mereka dapat meningkatkan pendapatan, penghidupan mereka, dan dan kapasitas untuk memproduksi, dan secara mendasar suatu jalan lapang di mana mereka dapat menjamin ketahanan pangan mereka pada masa mendatang.

Salah satu komunitas yang tetap melestarikan tradisi pangan berbasis pangan lokal adalah Komunitas Molamahu di Kecamatan Pulubala Kabupaten Gorontalo. Komunitas ini memiliki memiliki tradisi mengkonsumsi jagung sebagai makanan pokok. Tindakan sosial yang melandasi masyarakat Molamahu memilih jagung sebagai makanan pokok, pola tindakan sosialnya mengarah kepada dua pola, yaitu tindakan sosial rasionalitas instrumental dan tindakan sosial tradisional. Pola tindakan rasionalitas instrumental, yaitu tindakan individu-individu di masyarakat yang diarahkan kepada suatu tujuan berdasarkan kriteria tertentu dalam menentukan suatu pilihan. ${ }^{4}$ Dalam konteks ini tindakan masyarakat Desa Molamahu pada awalnya sebagai bentuk adaptasi terhadap lingkungan geografis yang berbukit-bukit serta lahan kering, selain itu untuk memenuhi sumber pangan jagung bisa dipanen muda, jagung juga mudah diolah. Tipologi tindakan sosial kedua adalah tindakan tradisional, yaitu tindakan yang dilakukan berulang-ulang dan telah berlangsung secara turun temurun.

\footnotetext{
4 Amir Fadhilah \& Badri Yatim, 2009, Kearifan Lokal Sebagai Modal Sosial Ketahanan Pangan Masyarakat : Studi Kasus pada Masyarakat Kp. Cireundeu KeLurahan Leuwi Gajah Kecamatan Cimahi Selatan Kota Cimahi Provinsi Jawa Barat, Desa Molamahu Kecamatan Pulubala Kabupaten Gorontalo Provinsi Gorontalo , Komunitas Baduy Desa Kenekes Kecamatan Leuwidamar Kabupaten Lebak Provinsi Banten (Laporan Penelitian Kompetitif 2009), Jakarta, Lembaga Penelitian UIN Syarif Hidayatullah Jakarta
} 
Pola makan pada dasarnya merupakan konsep budaya bertalian dengan makanan yang banyak dipengaruhi oleh unsur sosial budaya yang berlaku dalam kelompok masyarakat itu, seperti nilai sosial, norma sosial dan norma budaya bertalian dengan makanan, makanan apa yang dianggap baik dan tidak baik ${ }^{5}$.

Makanan tidaklah semata-mata
sebagai produk organik hidup dengan kualitas biokimia, tetapi makanan dapat dilihat sebagai gejala budaya. Gejala budaya terhadap makanan dibentuk karena berbagai pandangan hidup masyarakatnya. Suatu kelompok masyarakat melalui pemuka ataupun mitos-mitos (yang beredar di masyarakat) akan mengijinkan warganya memakan makanan yang boleh disantap dan makanan yang tidak boleh disantap ${ }^{6}$. "Ijin" tersebut menjadi semacam pengesahan atau legitimasi yang muncul dalam berbagai peraturan yang sifatnya normatif. Masyarakat akan patuh terhadap hal itu.

Munculnya pandangan tentang makanan yang boleh dan tidak boleh disantap menimbulkan kategori "bukan makanan" bagi makanan yang tidak boleh disantap. Hal itu juga memunculkan pandangan yang membedakan antara nutrimen (nutriment) dengan makanan (food). Nutrimen adalah konsep biokimia yaitu zat yang mampu untuk memelihara dan menjaga kesehatan organisme yang memakannya. Sedang makanan (food) adalah konsep budaya, suatu pernyataan yang berada pada masyarakat tentang makanan yang dianggap boleh dimakan dan

5 Sediaoetama AD., 1999, Imu Gizi untuk Mahasiswa dan Profesi Jilid II. Jakarta : Dian Rakyat

${ }^{6}$ Irmayanti Meliono Budianto, 2004, Dimensi Etis Terhadap Budaya Makan dan Dampaknya pada Masyarakat, Jurnal Makara sosial Humaniora, Vol. 8 No. 2, Agustus 2004, Fakultas Ilmu Pengetahuan Budaya UI yang dianggap tidak boleh dimakan dan itu bukan sebagai makanan ${ }^{7}$.

Kategori terhadap makanan yang muncul adalah makanan yang boleh dimakan dan makanan yang tidak boleh dimakan. Kategori tersebut berasal dari latar belakang budaya masyarakat yang mengijinkan orang untuk memakan makanan tertentu. Latar belakang budaya dapat berasal dari pandangan tradisional atau adat istiadat, pandangan hidup (way of life) ataupun agama. Memakan makanan yang diijinkan berarti patuh dan taat pada norma budaya yang ada, tetapi sekaligus membawa "keselamatan" bagi dirinya agar tidak berada pada jalan sesat atau melakukan pelanggaran. Makanan yang tidak boleh dimakan berarti makanan tersebut dianggap sebagai makanan yang tidak sepatutnya dimakan (haram) karena tidak dijinkan oleh norma budaya yang ada dan agama. Orang akan tidak bahagia atau keselamatan terancam karena memakan makanan yang seharusnya tidak boleh dimakan.

Mengacu pada pemikiran di atas, tujuan pembahasan kajian ini adalah : (1). untuk memahami konsep kearifan lokal dan relevensinya dalam membentuk budaya pangan lokal masyarakat pedesaan di Indonesia (kasus Komunitas Molamahu). (2). Untuk membahas peran dan fungsi kearifan lokal dalam membentuk budaya pangan lokal.

\section{B. Pembahasan}

\section{Makna Budaya Pangan}

Studi tentang makanan dalam konteks budaya merujuk pada persoalanpersoalan praktis serta perilaku konkret masyarakatnya. Sebagian dari kita memang cenderung menilai orang lain dari selera budaya makannya.Tanpa kita sadari dalam

\footnotetext{
${ }^{7}$ Foster, George M dan Barbara Gallatin Anderson. 1986. Antropologi Kesehatan. Penerjemah Priyanti Pakan Suryadarma dan Meutia F. Hatta Swasono, Jakarta: UI Press
} 
pergaulan antar sukubangsa atau antar bangsa telah terbentuk semacam stereotip etnik berdasarkan budaya makan; bukan hanya stereotip pada budaya makan tradisional, tapi juga pada budaya makan masa kini ${ }^{8}$. Di masa kini kita masih mengidentikkan bangsa-bangsa tertentu dengan kebiasaan makan kebanyakan warganegaranya, seperti macaroni dan pizza bagi bangsa Itali, keju bagi bangsa Belanda dan Skandinavia; kentang bagi bangsa Irlandia; ayam, kentang goreng dan daging bagi bangsa Amerika; jagung bagi bangsa Mexico; sea-foods bagi bangsa Jepang; mie bagi bangsa Cina; nasi goreng dan sambal pedas bagi bangsa Indonesia.

Keterikatan sosial pada makanan muncul ketika makanan itu disajikan pada berbagai peristiwa yang dialami oleh individu maupun masyarakat. Peristiwa yang mengacu pada siklus kehidupan manusia seperti kelahiran, menikah, dan kematian selalu dihadirkan dan ditandai dengan berbagai ritual yang dilengkapi dengan adanya ragam makanan, dan makan bersama baik dengan anggota keluarga maupun teman. Kebersamaan menjadi inti dari keterikatan masyarakat ketika makan bersama pada ritual tersebut. Cara penyajian makanan dibedakan dan disajian untuk kebutuhan sehari-hari maupun untuk sesaji yang bersifat ritual keagamaan ${ }^{9}$, cara penyajian makanan untuk sehari-hari adalah sederhana, sedangkan untuk pesta atau upacara lebih rumit, bahkan tampak lebih sedap dipandang daripada dimakan.

\footnotetext{
${ }^{8}$ Zulyani Hidayah, 2010, Rasa dan Keanekaragaman Citra Rasa Nusantara, Makalah dalam Sarasehan Nasional Antropologi 2010 'Rejinvensi Antropologi Indonesia di Era Demokrasi dan Globalisasi, Cisarua Bogor $21-23$ Juli 2010
}

9 Arif Budi W., 2008, Apek Budaya pada Tradisi Kuliner Tradsional di Kota Malang sebagai Identitas Budaya : Sebuah Tinjauan Folklore, Malang : Lembaga Penelitian Universitas Muhammadiyah Malang
Konsumsi makanan pokok merupakan proporsi terbesar dalam susunan hidangan di Indonesia, karena dianggap terpenting di antara jenis makanan lain. Suatu hidangan bila tidak mengandung bahan makanan pokok dianggap tidak lengkap oleh masyarakat. Makanan pokok seringkali mendapat penghargaan lebih tinggi oleh masyarakat dibanding lauk-pauk. Orang merasa puas asalkan bahan makanan pokok tersedia lebih besar dibanding jenis makanan lain. Di sisi lain makanan dalam pandangan sosial budaya, memiliki makna lebih luas dari sekedar sumber gizi ${ }^{10}$, hal ini terkait dengan kepercayaan, status, prestis, kesetiakawanan dan ketentraman dalam kehidupan manusia

\section{Makna Kearifan Lokal}

Kearifan dapat dijelaskan dalam cakupan tacit knowledge (TK) yang merupakan jantungnya kearifan ${ }^{11}$. Ia adalah pengetahuan informal yang tidak diajarkan disekolah seperti tradisi di mana pengetahuan formal dibelajari dan diprioritaskan. Kearifan akan memediasi nilai yang didukung oleh kinerja inteligensi praktis. Secara lebih jelas kearifan merupakan aplikasi antara tacit (pengetahuan yang paling dalam) dengan pengetahuan eksplisit sebagai mediasi nilai untuk pencapaian kebaikan bersama melalui keseimbangan diantara faktor-faktor : intrapersonal, (b) interpersonal, kepentingan ekstrapersonal baik dalam jangka pendek atau panjang untuk mencapai keseimbangan antara (1) adaptasi pada lingkungan yang ada, (2) membentuk lingkungan yang ada, (3) dan mampu menyeleksi lingkungan yang baru.

10 Wahida Y. Mapandin, 2006, Hubungan Faktorfaktor Sosial Budaya dengan Konsumsi Makanan Pokok Rumah Tangga pada Masyarakat di Kecamatan Waena, Kabupaten Jayawijaya, Tesis pada Magister Gizi Masyarakat Program Pascasarjana Universitas Diponegoro Semarang

${ }^{11}$ Sternberg, R.J. 2001. Why Schools Teach for Wisdom : The Balance Theory o 
Sternberg (2001) melihat kearifan sebagai pengetahuan yang menyeimbangkan keinginan hidup manusia. Menurutnya, di setiap kehidupan, orang akan membentuk nilai dirinya tergantung pada keinginan dominannya. Namun demikian nilai itu juga sangat tergantung pada tujuan yang sejalan untuk mencapai kebaikan pada umumnya. Dalam konteks teori keseimbangan, kearifan secara praktis merupakan inti pengetahuan yang tersembunyi (tacit knowledge) dan sebagai pengetahuan yang menyeimbangkan kepentingan.

untuk $\begin{gathered}\text { Kearifan lokal merupakan usaha } \\ \text { menemukan kebenaran yang }\end{gathered}$
didasarkan pada fakta-fakta atau gejalagejala yang berlaku secara spesifik dalam sebuah budaya masyarakat tertentu. Definisi ini bisa jadi setara dengan definisi mengenai indigenous psychology yang didefinisikan sebagai usaha ilmiah mengenai tingkah-laku atau pikiran manusia yang asli (native) yang tidak ditransformasikan dari luar dan didesain untuk orang dalam budaya tersebut 12. Hasil akhir dari indigenous psychology adalah pengetahuan yang menggambarkan tentang kearifan lokal, yaitu gambaran mengenai sikap atau tingkah-laku yang mencerminkan budaya asli.

Menurut Sony Keraf (2002) kearifan tradisional (lokal) merupakan bentuk pengetahuan, keyakinan, pemahaman atau wawasan serta adat kebiasaan atau etika manusia yang menuntun perilaku manusia dalam kehidupan di dalam komunitas ekologis. Jadi kearifan tradisional bukan hanya menyangkut pengetahuan, alam, dan pemahaman masyarakat adat tentang manusia dan bagaimana relasi yang baik diantara manusia, melainkan juga menyangkut pengetahuan, pemahaman dan adat kebiasaan manusia, alam dan

12 Setiono K., 2002, Pengembangan Psikologi Indigenous di Indonesia, dalam Jurnal Ilmiah Psikologi 'Kognisi' UMS Volume 6, Nomor 2 Nopember 2002 bagaimana relasi diantara semua penghuni komunitas ekologis ini harus dibangun ${ }^{13}$.

\section{Makna Ketahanan Pangan}

Mengacu pada Peraturan Pemerintah Nomor 68 tahun 2002 tentang Ketahanan pangan, pengertian ketahanan pangan diartikan sebagai kondisi terpenuhinya pangan bagi rumah tangga yang tercermin dari tersedianya pangan yang cukup, baik jumlah maupun mutunya, aman, merata dan terjangkau. Ketahanan pangan merupakan hal yang penting dan strategis, karena berdasarkan pengalaman di banyak negara menunjukkan bahwa tidak ada satu negarapun yang dapat melaksanakan pembangunan secara mantap sebelum mampu mewujudkan ketahanan pangan terlebih dahulu. Undang-undang Nomor 7 Tahun 1996 tentang Pangan mengamanatkan bahwa pemerintah bersama masyarakat mewujudkan ketahanan pangan bagi seluruh rakyat Indonesia.

Ketahanan pangan menyangkut ketersediaan dan keterjangkauan terhadap pangan yang cukup dan bermutu. Dalam hal ini terdapat aspek pasokan (supply), yang mencakup produksi dan distribusi pangan ${ }^{14}$. Disamping itu juga terdapat aspek daya beli, yang mencakup pula tingkat pendapatan individu dan rumah tangga. Juga terdapat aspek aksesibilitas setiap orang terhadap pangan, yang berarti mencakup hal yang berkaitan dengan keterbukaan dan kesempatan individu dan keluarga mendapatkan pangan.

Ketahanan pangan ini harus mencakup aksesibilitas, ketersediaan,

\footnotetext{
${ }^{13}$ Keraf, A. Sonny, 2002, Etika Lingkungan, Penerbit Buku Kompas, Jakarta

14 Krisnamurthi Bayu, 2005, Perum Bulog Dan Kebijakan Pangan Indonesia: Kendaraan Tanpa Tujuan?, http://www.ekonomirakyat.org/edisi_19/artikel_2.ht m, diakses pada tanggal 15 Desember 2005
} 
keamanan dan kesinambungan 15. Aksesibilitas di sini artinya setiap rumah tangga mampu memenuhi kecukupan pangan keluarga dengan gizi yang sehat. Ketersediaan pangan adalah rata-rata pangan dalam jumlah yang memenuhi kebutuhan konsumsi di tingkat wilayah dan rumah tangga. Sedangkan keamanan pangan dititikberatkan pada kualitas pangan yang memenuhi kebutuhan gizi.

Ketahanan pangan erat kaitannya dengan ketahanan sosial, stabilitas ekonomi, stabilitas politik dan keamanan atau ketahanan nasional ${ }^{16}$. Bahkan ketahanan pangan dalam arti keterjangkauan pangan juga berkaitan erat dengan upaya peningkatan mutu sumberdaya manusia Indonesia. Tanpa dukungan pangan yang cukup dan bermutu, mustahil akan dihasilkan sumberdaya manusia yang bermutu. Oleh karena itu tidak mengherankan jika isu ketahanan pangan ini telah menjadi salah satu fokus utama dalam kebijakan operasional pembangunan pertanian dalam periode Kabinet Persatuan Nasional dan Kabinet Gotong Royong (1999-2004), hingga sekarang dalam Kabinet Indonesia Bersatu (2004-2009) ${ }^{17}$.

\section{Bentuk Kearifan Lokal pada masyarakat Desa Molamahu, Kecamatan Pulubala, Kabupaten Gorontalo, Provinsi Gorontalo}

\footnotetext{
15 Martaja, 2005, Solidaritas Nasional Ketahanan Pangan, http://www.sinarharapan.co.id/berita/0510/26/opi02.h tml. Diakses tanggal 26 Oktober 2005

${ }^{16}$ Suryana, A. 2001.Tantangan dan Kebijakan Ketahanan Pangan. Makalah disampaikan pada Seminar Nasional Pemberdayaan Masyarakat untuk Mencapai Ketahanan Pangan dan Pemulihan Ekonomi. Departemen Pertanian. Jakarta 29 Maret. 2001

17 Salim, H.P., 2004. Indikator Penentu, Karakteristik, Dan Kelembagaan Jaringan Deteksi DiniTentang Kerawanan Pangan. Icaserd Working Paper No. 46. No. Dok.058.46.04.04. Pusat Penelitian dan Pengembangan Sosial Ekonomi Pertanian Jl. A. Yani No. 70 Bogor 16161
}

Desa Molamahu merupakan salah satu wilayah di Kecamatan Pulubala, Kabupaten Gorontalo , Provinsi Gorontalo dengan luas wilayah $2.658 \mathrm{Ha}$ yang terdiri dari $30 \mathrm{Ha}$ areal sawah (sekitar 1,13\%), 925,3 Ha areal ladang/tegalan (sekitar $34,81 \%), 350.25 \mathrm{Ha}$ areal perkebunan (sekitar 13,18\%) , 525,25 Ha areal pekarangan (sekitar 19,76\%), dan sekitar $31,12 \%$ atau seluas 827,1 Ha merupakan areal lain-lain seperti fasiitas umum (lapangan, kuburan, tanah desa, fasilitas umum). Agama yang dianut penduduk Desa Molamahu mayoritas Islam, yaitu sekitar 99,79\% atau sebanyak 1.929 jiwa, sedang peganut agama lainnya hanya agama Kristen Protestan sekitar $0,21 \%$ atau sebanyak 4 jiwa. ${ }^{18}$

Komoditi pertanian dan perkebunan di Desa Molamahu cukup beragam, dari luas areal 963 Ha terdiri dari tanaman padi sawah seluas 30 atau sekitar 3,12\% dengan hasil produksi $1.350 \mathrm{kwintal}$ (rata-rata 45 $\mathrm{Kwt} / \mathrm{Ha}$ ), jagung seluas $710 \mathrm{Ha}$ atau sekitar $73,73 \%$ dengan hasil produksi 39.050 kwintal (rata-rata $55 \mathrm{Kwt} / \mathrm{Ha}$ ), Ubi kayu (singkong) seluas $1 \mathrm{Ha}$ atau sekitar $0,10 \%$ dengan hasil produksi $85 \mathrm{Kwintal}$ (rata-rata $85 \mathrm{Kwt} / \mathrm{Ha}$ ), Ubi jalar seluas $1 \mathrm{Ha}$ atau sekitar $0,10 \%$ dengan hasil produksi 84 kwintal (rata-rata $84 \mathrm{Kwt} / \mathrm{Ha}$ ), Kacang tanah seluas $20 \mathrm{Ha}$ atau sekitar 2,08 \% dengan hasil produksi 300 kwintal (rata-rata 15 Kwt/Ha), Kacang hijau seluas $1 \mathrm{Ha}$ atau sekitar $0,10 \%$ dengan hasil produksi 12 kwintal (rata-rata $12 \mathrm{Kwt} / \mathrm{Ha}$ ), kelapa seluas $150 \mathrm{Ha}$ atau sekitar $15,58 \%$ dengan hasil produksi 1.488 kwintal (rata-rata 9,92 Kwt/Ha), Kakao seluas $50 \mathrm{Ha}$ atau sekitar $5,19 \%$ dengan hasil produksi 250 kwintal (rata-rata $5 \mathrm{Kwt} / \mathrm{Ha}$ ). ${ }^{19}$

Berdasarkan data di atas dapat dilihat bahwa komoditi tanaman yang paling luas adalah tanaman jagung, yaitu seluas $710 \mathrm{Ha}$

\footnotetext{
${ }^{18}$ Monografi Desa Molamahu kondiis tahun 2009.

19 Camat Pulubala, 2009, Laporan Penduduk Kecamatan Pulubala bulan Mei 2009, Kantor Kecamatan Pulubala
} 
atau sekitar $73,73 \%$ darii luas lahan pertanian dan perkebunan. Kondisi ini tidak lepas dari kebasaan masyrakat Desa Molamahu menanam jagung sebagai sumber makanan pokok masyarakat

Masyarakat Desa Molamahu merupakan salah satu komunitas di wilayah Kabupaten Gorontalo yang secara turun temurun melestariakan dan mempertahankan adat leluhurnya. Bentuk-bentuk kearifan lokal yang masih terpelihara dan dijalankan dalam kehidupan sehari-hari masyarakat Molamahu disajikan pada matrik berikut ini:

Matrik 1. Aspek-aspek dan Bentuk

Kearifan Lokal Masyarakat Molamahu

\begin{tabular}{|c|c|}
\hline $\begin{array}{c}\text { ASPEK } \\
\text { KEARIFAN } \\
\text { LOKAL } \\
\end{array}$ & $\begin{array}{c}\text { BENTUK KEARIFAN } \\
\text { LOKAL }\end{array}$ \\
\hline \multirow[t]{7}{*}{$\begin{array}{l}\text { Aspek } \\
\text { Material }\end{array}$} & $\begin{array}{l}\text { * Berladang budidaya } \\
\text { Jagung }\end{array}$ \\
\hline & $\begin{array}{l}\text { Makanan pokok } \\
\begin{array}{l}\text { Ba'alo binti } \\
\text { jagung) }\end{array}\end{array}$ \\
\hline & * $\begin{array}{ll}\text { Tradisi } \\
\text { mobisala }\end{array}$ \\
\hline & * Ritual Molotobu \\
\hline & Tradisi 'mutiayu \\
\hline & $\begin{array}{l}\text { * Tradisi 'taluwola to } \\
\text { hulipo', }\end{array}$ \\
\hline & $\begin{array}{l}\text { * Sistem Kalender } \\
\text { Musim Tanam lokal }\end{array}$ \\
\hline \multirow[t]{2}{*}{$\begin{array}{l}\text { Aspek Nilai / } \\
\text { gagasan }\end{array}$} & $\begin{array}{l}\text { * Perhitungan hari baik } \\
\text { berdasarkan } \\
\text { 'Lowena' dan } \\
\text { 'Kalisuwo' }\end{array}$ \\
\hline & $\begin{array}{l}\text { * Semboyan } \\
\text { "...Tooutonu } \\
\text { opilmulo lo bongo } \\
\text { suburu teto mali } \\
\text { pomolowalo } \\
\text { sababu binte } \\
\text { suburu olo.." }\end{array}$ \\
\hline
\end{tabular}

Sumber : di adopsi dari Amir Fadhilah \& Badri Yatim (2009)

Berdasarkan matrik di atas dapat dilihat ada beberapa bentuk kearifan lokal yang berlaku pada masyarakat Molamahu, baik dalam bentuk material ataupun non material, yaitu :

Pertama, berladang budidaya jagung. Secara turun temurun pola pertanian yang diterapkan masyarakat Molamahu adalah sistem pertanian di lahan kering dengan komoditi utama jagung. Tradisi membudidayakan jagung di kalangan masyarakat Molamahu pada dasarnya sebagai bentuk adaptasi terhadap lingkungan sekitarnya yang memiliki kondisi topografi lahan berbukit dan kering yang mengandalkan pola tadah hujan. Pada dasarnya tradisi menanam dan mengkonsumsi jagung sudah ada sejak jaman dulu. Kondisi ini tidak lepas dari kebanyakan lahan pertanian yang dimiliki masyarakat Kabupaten Gorontalo pada umumnya dalam bentuk ladang/huma yang tersebar pada dataran perbukitan dan kondisi lahan miring. Kondisi tanah demikian kurang baik dan sukar kalau digunakan untuk pola pertanian sistem sawah. Kondisi ini mendorong masyarakat menanam jagung sebagai sumber makanan pokok masyarakat..

Kedua, tradisi mengkonsumsi Ba'alo binti (beras jagung) sebagai makanan pokok. Karakteristik kearifan lokal dalam bentuk mengkonsumsi jagung muncul sebagai bentuk adaptasi terhadap kondisi lingkungan sekitarnya. Tradisi mengkonsumsi jagung sebagai makanan pokok masyarakat Molamahu berjalan secara turun temurun sampai sekarang. Keberadaan jagung sebagai makanan pokok masyarakat Molamahu tidak hanya semata-mata untuk memenuhi kebutuhan hidup saja, akan tetapi jagung juga digunakan dalam kegiatan ritual keagamaan, seperti : untuk membayar zakat fitrah ${ }^{20}$. Kondisi ini menunjukkan bahwa

20 Bagi masyarakat Molamahu, Ba'alo binti (beras jagung) selain sebagai sumber makanan pokok, juga 
pemanfaatan Ba'alo binti dalam berbagai aspek kehidupan sudah melekat pada kebiasan masyarakat Molamahu. ${ }^{21}$

Ketiga, Tradisi Jaowali mobisala, yaitu kebiasaan masyarakat dalam melakukan kegiatan menanam jagung harus konsentrasi dan tidak diperbolehkan sambil bicara diantara orang-orang yang sedang terlibat dalam kegiatan menanam jagung. Tujuan tradisi Jaowali mobisala adalah agar hasil tanaman lebih baik karena orang mengerjakannya secara sungguh dan teliti. Kearifan lokal ini sampai sekarang masih tetap dijalnkan masyarakat Molamahu. ${ }^{22}$

Keempat, Ritual Molotobu, yaitu tradisi memberikan 5 buah tongkol jagung

digunakan pada kegiatan peribadatan. Sebagai contoh pada saat Bulan Ramadhan terutama terkait dengan pelaksanaan pembayaran zakat fitrah, masyarakat membayarnya zakatnya tetap memakai standar Ba'alo binti. Walaupun kadang lebih banyak dibayarkan dalam bentuk uang, namun standar nilainya disesuaikan dengan standar harga ba'alo binti. Tradisi mengkonsumsi jagung sudah berjalan sejak jaman dulu, kenapa masyarakat sini memilih jagung sebagai sumber makan pokoknya ada beberapa alasan antara lain : (1). Hasil tanaman jagung dapat langsung dikonsumsi dan pengolahannya mudah. (2). Menurut kami dengan memakan jagung kami lebih kuat dan merasa lebih lama tahan laparnya. (3). Apabila ada keperluan mendesak jagung dapat juga dipanen muda. (4). Jagung dapat diolah menjadi beragam bentuk makanan, seperti :Kue 'Bente telene', yaitu jagung muda yang dibakar dengan kulitnya rasa manis dan tidak keras. 'Kokoleh', yaitu kue dari jagung muda, 'Ba'alo binti (beras jagung). Informasi lebih lanjut dapat di baca pada laporan penelitian kompetitif 2009 (amir fadhilah \& Badri yatim, 2009)

${ }^{21}$ Ketika banyak orang memilih makan beras sebagai makanan pokok, orang Gorontalo telah lama makan jagung. Komoditas jagung terkait dengan budaya masyarakat Gorontalo”. Lagu rakyat Binte Biluhuta, yang sebagian syairnya menggambarkan masyarakat doyan makan jagung dan setiap rumah di sana tak mau ketinggalan makan jagung, cukup untuk menunjukkan sejarah jagung Gorontalo

22 Tradisi 'Jamowali Mobisala', yaitu tradisi pada saat menanam (menaruh bibit dilobang tanah) tidak boleh sambil bicara. Tujuan ritual ini disamping diharapkan hasilnya akan baik, juga agar terhindar dari binatang perusak, seperti babi hutan kepada tetangganya sebelum tanaman jagung dipanen. Jagung yang diberikan diambil dari 5 titik areal lahan tanaman jagung, yaitu 4 buah dari setiap pojok lahan, dan 1 titik ditengah-tengah lahan. Pesan yang dibawa oleh tradisi ini adalah agar ada keseimbangan dalam kehidupan manusia dengan selalu mengingat tetangga disekelilingnya. ${ }^{23}$

Kelima, Tradisi Mutiayu, yaitu kebiasan yang menyatukan petani dalam kegiatan dan aktivitas pertanian sejak dari proses membersihkan lahan, membajak lahan, merawat tanaman sampai dengan memanen secara gotong royong. Tradisi mutiayu sempat mengalami perubahan ketika Pemerintah Provinsi Gorontalo mengeluarkan kebijakan Program Agropolitan, dan Pemerintah Kabupaten Gorontalo mengeluarkan kebijakan program Agropotombulu. Salan satu bentuk paket program tersebut adalah penyediaan traktor 1 unit untuk setiap desa yang operasionalnya di koordinir melalui wadah pengurus Agropotumbolo ditingkat desa. Salah satu dampak dari program ini adalah adanya perubahan nilai-nilai yang terkandung di dalam tradisi mutiayu, yaitu semangat gotong royong, tergantikan dengan sistem upah. Kondisi ini menunjukkan bahwa proses modernisasi peralatan dan kelembagaan yang dipaksakan untuk menggantikan tradisi lokal berdampak pada memudarnya kearifal lokal yang menjunjung tinggi nilai kerja sama berdasarkan kebersamaan diganti semangat kerja yang dilandasi nilai-nilai ekonomi dengan sistem upah. Namun demikian tidak semua aspek

23 Sebelum dipanen masyarakat Molamahu melakukan ritual 'Molotobu', yaitu mengambil jagung pada setiap pojok lahannya masing-masing sebanyak 1 buah, dan satu buah lagi ditengah-tengah lahannya, jadi sebelum proses pemanen diambil dulu 5 buah jagung yang sudah kering. Jagung tersebut akan disedekahkan kepada tetangganya. Ritual ini dipercaya untuk menghindari hama babi hutan pada musim tanam berikutnya, disamping itu apabila tidak mensedahkan kepada tetangga dipercaya yang bersangkutan akan kena bala penyakit 
yang terkandung dalam tradisi mutiayu mengalami kepudaran

Keenam, Tradisi 'Taluwola to hulipo', yaitu kebiasaan di masyarakat molamahu untuk menyimpan sebagian hasil panennya untuk cadangan stok pangan pada musim berikutnya. Secara adat masyarakat tidak diperbolehkan menjual semua hasil panennya, akan tetapi harus ada yang disimpan. ${ }^{24}$

Ketujuh, Sistem kalender musim tanam lokal, yaitu pola penanaman yang ditentukan berdasarkan perhitunganperhitungan yang mengacu pada kalender Bulan, dengan mempertimbangkan posisi bulan di langit untuk menentukan musim tanam. Penentuan musim tanam tersebut dipandu oleh seorang 'panggoba', yaitu orang yang memiliki kemampuan untuk membaca bintang dilangit dalam menentukan musim tanam di masyarakat. Di kalangan masyarakat Molamahu dikenal 3 musim yang terkait dengan aktivitas penanaman, yaitu : To'uwo, Tuwolongo dan Hulita. Deskripsi kategori pembagian musim tanam pada masyarakat Molamahu secara ringkas disajikan dalam uraian berikut ini : (1). To'uwo, yaitu musim tanam yang rame. Pada musim ini kalau berhasil akan menjadi panen raya masyarakat. Musim tanam ini pada tanggal 9/10 sampai dengan 26/10 yaitu sekitar bulan Oktober. Musim ini bagus untuk menanam. (2). Tuwolonga, yaitu musim tanam, akan tetapi tidak semua orang menanam. Musim ini jatuh pada

\footnotetext{
${ }^{24}$ Prinsip masyarakat Molamahu hasil panen jangan dijual semua, akan tetapi dibagi $20 \%$ untuk disimpan untuk jaga-jaga kalau ada kebutuhan mendadak, $30 \%$ untuk persiapan konsumsi sehari-hari. Dan sisanya sekitar 50\% boleh dijual untuk memenuhi kebutuhan hidup lainnya. Pada masa lalu ketika sarana transportasi sulit semua hasil panen ditumpuk/disimpan di 'ibungo' (lumbung). Kalau sekarang setelah sarana transportasi mudah, dalam arti infrastruktur jalan sebagian sudah diaspal dan akses kendaraaan dapat masuk ke desa maka polanya berubah. Sebagian hasil disimpan dan dikonsumsi, sedangkan sisanya dapat dijual. Informasi lebih lanjut dapat di baca pada laporan penelitian kompetitif 2009 (amir fadhilah \& Badri yatim, 2009).
}

tanggal 8 - 31 Maret. (3). Hulita, yaitu musim kering. Umumnya masyarakat tidak menanam, namun apabila ada yang menanam kalau berhasil harganya cukup tinggi karena stok panen sedikit, namun perlu kerja keras karena musim kemarau. Pada umumnya orang yang menanam pada musim Hulita adalah untuk persediaan bibit pada musim tanam berikutnya, yaitu To'uwo. Disamping musim tersebut apabila ada bintang dipertengahan tidak boleh menanam. Kalau terpaksa menanam pada saat naruh jagung pada lubang tanah sambil mengucapkan disuruh kepala desa (To'uda a tami itu de). Disamping itu pada kayu panjang diikat kain putih, apabila dilanggar yang bersangkutan bisa kena 'dungga la 'bala ' (musibah) bisa dalam bentuk sakit, tanaman kena hampa atau kehilangan sesuatu. ${ }^{25}$

Kedelapan, Perhitungan hari baik berdasarkan 'Lowena' dan 'Kalisuwo'. Tradisi masyarakat Molamahu dan sekitarnya apabila akan melakukan suatu aktivitas berdasarkan perhitungan hari baik. Kebiasaan ini dikenal dengan konsep "Lowena' dan 'Kalisuwo'. Secara harfiah Lowena diartikan sebagai hari kosong, sedangkan Kalisuwo diartikan sebagi kelesuan. Penentuan kedua hari tersebut mengacu pada sistem kalender Qomariah yang terbagi 12 bulan.

Sistem perhitungan hari-hari baik mengacu pada konsep 'Lowena' dan 'Kalisuwo'. Lowena diartikan kosong atau hari kosong. Sedang Kalisuwo artinya kelesuan, atau kadang diartikan seperti jalan tanpa kepala dalam arti tidak jelas tujuannya. Dua hari tersebut orang menghindari untuk menanam. Perhitungannya didasarkan pada kalender bulan Qomariah. Ssistemnya adalah mengacu pada Bulan Qomariah yang membagi bulan menjadi 12 , yaitu : (1)

25 Data ini peneliti peroleh dari buku catatan Pedoman Penentuan musim tanam menurut perhitungan bulan, milik keluarga Bapak Harun Musa seorang Panggoba di Desa Molamahu. Buku ini tidak dipublikasikan 
Muharam, (2) Safar, (3) Rabi'ul awal, (4) Rabi' ul Tsani, (5) Jumadil Ula, (6) Jumadil Tsani, (7) Rajab, (8) Sya'ban, (9) Ramadhan, (10) Syawwal, (11) Dzul Qa'dah, (12) Dzulhijjah. Kemudian penentuan hari buruknya mengacu pada rumusan : Arajusekasajukasesasenra sebagaiberikut :
(1) $\mathrm{A}=$ Ahad
(2) $\mathrm{Ra}=\mathrm{Rabu}$
(3) $\mathrm{Ju}=$ Jum'at
(4) $\mathrm{Se}=$ Selasa
(5) $\mathrm{Ka}=$ Kamis
(6) $\mathrm{Sa}=$ Sabtu
(7) $\mathrm{Ju}=$ Jum'at
(8) $\mathrm{Ka}=$ Kamis
(9) $\mathrm{Se}=$ Selasa
(10) $\mathrm{Sa} \quad=$ Sabtu
(11) Sen = Senen
(12) $\mathrm{Ra}=\mathrm{Rabu}$

Langkah berikutnya untuk mencari/menghindari buruk dicari dulu Lowenanya kemudian Kalisuwonya ditentukan pada hari berikutnya yang kategori Lowena, misalkan sekarang bulan Rajab (7) maka Lowenanya jatuh pada bilangan $7=$ jum'at. Kemudian Kalisuwonya adalah hari berikutnya, yaitu Sabtu. Namun ini hanya ihtiar manusia, hasil akhirnya diserahkan kepada Yang Maha Kuasa..." 26

Kesembilan, semboyan "Tooutonu opilmulo lo bongo suburu teto mali pomolowalo binte sababu binte mali suburu olo." Artinya dimana ada pohon kelapa subur, maka disekitarnya akan ditanam jagung karena akan subur juga. Semboyan ini melahirkan kearifan lokal dalam pola sistem tanaman tumpangsari antar pohon kelapa dengan jagung. Tradisi masyarakat Molamahu ketika ladang belum ada tanaman kerasnya akan ditanami pohon kelapa dengan pola tumpangsari dengan jagung..

\footnotetext{
${ }^{26}$ Data ini diperoleh dari Ir. Bakrin D. Igirisa (Camat Pulubala, tokoh adat di wilayah Kecamatan Pulubala, Kabupaten Gorontalo). Informasi lebih lanjut dapat di baca pada laporan penelitian kompetitif 2009 (amir fadhilah \& Badri yatim, 2009).
}

Sistem penanaman jagung dilakukan di area ladang/huma yang tersebar diperbukitan. Rata-rata sistem penanamannya adalah 2 kali musim (2 kali dalam setahun). Rata-rata luas tanaman yang dimiliki masyarakat berkisar, antara 0,5 s/d. 2 Ha. Salah satu bentuk kearifan lokal dalam konteks tanaman jagung adalah dilakukan sebagai bentuk tumpangsari dengan tanaman kelapa, karena di masyarakat ada semboyan "Dimana ada pohon kelapa subur, maka disekitarnya akan ditanam jagung karena akan subur juga' (Tooutonu opilmulo lo bongo suburu teto mali pomolowalo binte sababu binte mali suburu olo). Pola penanaman jagung yang dilakukan masyarakat Molamahu pada umumnya berdampingan dengan pohon kelapa dengan sistem tumpangsari.Pola ini akan berlangsung sampai pohon kelapa berbuah banyak. Pertimbangan pola tersebut adalah : pertama, kelapa untuk jangka dan cocok dengan kondisi lahan yang terbuka. Kedua, disisi lain sistem ini akan saling menyuburkan. ${ }^{27}$

\section{Peran dan Fungsi Kearifan Lokal dalam Membentuk Ketahanan Pangan Lokal (Kasus Molamahu)}

Kearifan lokal mewujud dalam kebiasaan-kebiasaan masyarakat yang memiliki pemahaman yang sama mengenai sesuatu baik dalam bentuk material maupun nilai/gagasan. Untuk kasus di Molamahu bentuk kearifan lokal dalam kategori material berupa pola berladang budidaya jagung, memakan Ba'alo binti (beras jagung), tradisi Jaowali mobisala, ritual Molotabu, tradisi mutiayu, tradisi taliwola to hulipo (tradisi menyimpan sebagian hasil panen), sistem kalender musim tanam lokal, sedangkan kearifan lokal dalam bentuk

\footnotetext{
${ }^{27}$ Informasi ini diperoleh dari Musa Harun (Mantan Ketua LKMD Desa Molamahu, Panggoba (tokoh adat yang memiliki kemampuan membaca kalender musim tanam dengan melihat posisi bulan di langit). Informasi lebih lanjut dapat di baca pada laporan penelitian kompetitif 2009 (amir fadhilah \& Badri yatim, 2009).
} 
nilai/gagasan berupaa Perhitungan hari baik berdasarkan 'Lowena' dan 'Kalisuwo' serta Semboyan : “...Tooutonu opilmulo lo bongo suburu teto mali pomolowalo binte sababu binte mali suburu olo.." yang mendorong lahirnya pola tanaman tumpangsari tanaman kelapa dengan tanaman jagung. Deskripsi kearifan lokal Masyarakat Desa Molamahu yang berpengaruh terhadap ketahanan sosial masyarakat disajikan pada matrik berikut ini

Matrik 2 Tipologi Kearifan Lokal yang Membentuk Budaya Pangan dan Ketahanan Pangan Lokal Masyarakat Desa Molamahu

\begin{tabular}{|c|c|c|}
\hline $\begin{array}{c}\text { ASPEK } \\
\text { BUDAYA } \\
\text { PANGAN } \\
\text { LOKAL }\end{array}$ & $\begin{array}{l}\text { BENTUK } \\
\text { KEARIFA } \\
\text { N LOKAL }\end{array}$ & $\begin{array}{c}\text { BENTUK } \\
\text { KETAHANA } \\
\text { N PANGAN } \\
\text { LOKAL }\end{array}$ \\
\hline \multirow[t]{6}{*}{ Material } & $\begin{array}{l}\text { * Berlada } \\
\text { ng } \\
\text { budiday } \\
\text { a } \\
\text { Jagung } \\
\end{array}$ & $\begin{array}{l}\text { Masyaraka } \\
\text { t memiliki } \\
\text { alternatif } \\
\text { sumber } \\
\text { pangan }\end{array}$ \\
\hline & $\begin{array}{l}\text { Makana } \\
\text { n pokok } \\
\text { Ba'alo } \\
\text { binti } \\
\text { (beras } \\
\text { jagung) }\end{array}$ & $\begin{array}{l}\text { Mandiri } \\
\text { pangan } \\
\text { dengan } \\
\text { Ba'alo } \\
\text { binti } \\
\text { (beras } \\
\text { jagung) }\end{array}$ \\
\hline & $\begin{array}{l}\text { Tradisi } \\
\text { Jaowali } \\
\text { mobisal } \\
\text { a } \\
\end{array}$ & $\begin{array}{l}\text { Peningkata } \\
\text { n hasil } \\
\text { panen } \\
\text { jagung }\end{array}$ \\
\hline & $\begin{array}{l}\text { Ritual } \\
\text { Molotob } \\
\mathrm{u} \\
\end{array}$ & $\begin{array}{l}\text { Terpelihar } \\
\text { anya relasi } \\
\text { sosial }\end{array}$ \\
\hline & $\begin{array}{l}\text { Tradisi } \\
\text { 'mutiay } \\
\mathrm{u} \\
\end{array}$ & $\begin{array}{l}\text { Terpelihar } \\
\text { anya relasi } \\
\text { sosial }\end{array}$ \\
\hline & $\begin{array}{l}\text { * Tradisi } \\
\text { 'taluwol } \\
\text { a to }\end{array}$ & $\begin{array}{l}\text { Stabilitas } \\
\text { stok } \\
\text { pangan }\end{array}$ \\
\hline
\end{tabular}

\begin{tabular}{|c|c|c|}
\hline \multirow[t]{3}{*}{$\begin{array}{c}\text { ASPEK } \\
\text { BUDAYA } \\
\text { PANGAN } \\
\text { LOKAL } \\
\end{array}$} & $\begin{array}{l}\text { BENTUK } \\
\text { KEARIFA } \\
\text { N LOKAL }\end{array}$ & $\begin{array}{c}\text { BENTUK } \\
\text { KETAHANA } \\
\text { N PANGAN } \\
\text { LOKAL }\end{array}$ \\
\hline & hulipo', & \\
\hline & $\begin{array}{l}\text { Sistem } \\
\text { Kalende } \\
\text { r Musim } \\
\text { Tanam } \\
\text { lokal }\end{array}$ & $\begin{array}{l}\text { Sistem } \\
\text { tanam } \\
\text { yang } \\
\text { mengacu } \\
\text { pada } \\
\text { kondisi } \\
\text { alam }\end{array}$ \\
\hline \multirow[t]{2}{*}{$\begin{array}{c}\text { Nilai/Gaga } \\
\text { san }\end{array}$} & $\begin{array}{l}\text { Perhitun } \\
\text { gan hari } \\
\text { baik } \\
\text { berdasar } \\
\text { kan } \\
\text { 'Lowen } \\
\text { a' dan } \\
\text { 'Kalisu } \\
\text { wo' }\end{array}$ & $\begin{array}{l}\text { Tersediany } \\
\text { a aturan } \\
\text { lokal yang } \\
\text { terkait } \\
\text { dengan } \\
\text { pelestaria } \\
\text { n } \\
\text { lingkunga } \\
\text { n budaya }\end{array}$ \\
\hline & $\begin{array}{l}\text { Semboy } \\
\text { an : } \\
\text { “...Toou } \\
\text { tonu } \\
\text { opilmul } \\
\text { o lo } \\
\text { bongo } \\
\text { suburu } \\
\text { teto } \\
\text { mali } \\
\text { pomolo } \\
\text { walo } \\
\text { binte } \\
\text { sababu } \\
\text { binte } \\
\text { mali } \\
\text { suburu } \\
\text { olo..” }\end{array}$ & $\begin{array}{l}\text { Tumbuhny } \\
\text { a sistem } \\
\text { tumpangsa } \\
\text { ri tanaman } \\
\text { kelapa } \\
\text { dengan } \\
\text { tanaman } \\
\text { jagung }\end{array}$ \\
\hline
\end{tabular}

Sumber : di adopsi dari Amir Fadhilah \& Badri Yatim (2009)

Berdasarkan matrik di atas dapat dilihat bahwa ada keterkaitan antara dimensi-dimensi ketahanan sosial dengan tipologi kearifan lokal yang akan berpengaruh terhadap bentuk ketahanan 
sosial masyarakat. Deskripsi tipologi kearifan lokal yang membentuk ketahanan sosial masyarakat Desa Molamahu disajikan dalam uraian berikut ini :

Pertama, kearifan lokal dalam bentuk berladang budidaya jagung sudah dilaksanakan secara turun temurun oleh masyarakat Molamahu. Tipologi kearifan lokal ini pada dasarnya sebagai bentuk adaptasi terhadap lingkungan sekitarnya yang memiliki kondisi topografi lahan berbukit dan kering yang mengandalkan pola tadah hujan, sehingga kurang cocok untuk tanaman padi. Tipologi kearifan lokal berladang budidaya jagung mendorong masyarakat melakukan usaha untuk memenuhi sumber pangan dengan tanaman jagung, dan hasilnya masyarakat dapat memenuhi kebutuhan hidupnya dari hasil budidaya jagung. Kearifan lokal ini berdampak pada ketahanan sosial masyarakat dalam bentuk memiliki alternatif sumber pangan.

Kedua, kearifan lokal dalam bentuk mengkonsumsi Ba'alo binti (beras jagung) sebagai makanan pokok. Tipologi kearifan lokal ini muncul sebagai bentuk adaptasi terhadap kondisi lingkungan sekitarnya. Tradisi mengkonsumsi jagung sebagai makanan pokok masyarakat Molamahu sudah berjalan secara turun temurun sampai sekarang. Masyarakat Molamahu tidak pernah mengalami kelaparan walaupun ada kelangkaan beras, karena masyarakat secara mandiri telah memiliki sumber pangan sendiri, yaitu Ba'alo binti (beras jagung). Kearifan lokal dalam bentuk mengkonsumsi Ba'alo binti (beras jagung) sebagai makanan pokok yang berbasis pada sumber pangan lokal menumbuhkan kemandirian pangan di masyarakat Molamahu. Kearifan lokal tersebut berdampak pada munculnya ketahanan sosial masyarakat dalam bentuk 'mandiri pangan dengan Ba'alo binti'.

Ketiga, kearifan lokal dalam bentuk tradisi Jaowali mobisala, yaitu kebiasaan masyarakat dalam melakukan kegiatan menanam jagung harus konsentrasi dan tidak diperbolehkan sambil bicara diantara orang-orang yang sedang terlibat dalam kegiatan menanam jagung. Tujuan tradisi Jaowali mobisala adalah agar hasil tanaman lebih baik karena orang mengerjakannya secara sungguh dan teliti. Dengan sistem penanaman yang teliti diharapkan hasilnya akan lebih baik. Tipologi kearifan lokal dalam bentuk tradisi Jaowali mobisala berdampak pada munculnya ketahananan sosial masyarakat dalam bentuk 'Peningkatan hasil panen jagung'. Bentuk ketahanan sosial ini tidak lepas dari aktivitas menanam yang dilarang sambil bicara memberi dampak pada proses penanaman yang lebih sungguh-sungguh dan teliti.

Keempat, kearifan lokal dalam bentuk Ritual Molotobu, yaitu tradisi memberikan 5 buah tongkol jagung kepada tetangganya sebelum tanaman jagung dipanen. Jagung yang diberikan diambil dari 5 titik areal lahan tanaman jagung, yaitu 4 buah dari setiap pojok lahan, dan 1 titik ditengah-tengah lahan. Tipologi kearifan lokal ini bertujuan agar manusia selalu ingat dan berbuat baik dengan tetangganya. Tipologi kearifan lokal ini berdampak pada munculnya ketahanan sosial masyarakat dalam bentuk 'terpeliharanya relasi sosial' .

Kelima, kearifan lokal dalam bentuk Tradisi Mutiayu, yaitu kebiasan yang menyatukan petani dalam kegiatan dan aktivitas pertanian sejak dari proses membersihkan lahan, membajak lahan, merawat tanaman sampai dengan memanen secara gotong royong. Tipologi kearifan lokal tersebut menumbuhkan semangat jaringan kerja antar anggota masyarakat. Kearifan lokal dalam bentuk tradisi mutiayu berdampak pada munculnya ketahanan sosial masyarakat dalam bentuk 'terpeliharanya relasi sosial'. Kondisi tersebut tercipta karena didukung semangat gotong royong.

Keenam, kearifan lokal dalam bentuk Tradisi 'Taluwola to hulipo', yaitu kebiasaan di masyarakat molamahu untuk menyimpan sebagian hasil panennya sebagai cadangan stok pangan pada musim berikutnya. Hasil panen yang diperoleh 
masyarakat tidak secara adat tidak diperbolehkan dijual semua, akan tetapi harus ada yang disimpan untuk konsumsi sehari-hari ataupun untuk jaminan stok pangan. Tradisi ini sudah berjalan secara turun temurun. Tipologi kearifan lokal dalam bentuk tradisi 'Taluwola to hulipo' berdampak pada munculnya ketahanan sosial masyarakat dalam bentuk 'stok pangan yang terjamin'.

Ketujuh, Kearifa lokal dalam bentuk Sistem kalender musim tanam lokal yaitu pola penanaman yang ditentukan berdasarkan perhitungan-perhitungan yang mengacu pada kalender Bulan, dengan mempertimbangkan posisi bulan di langit untuk menentukan musim tanam. Penentuan musim tanam tersebut dipandu oleh seorang 'panggoba', yaitu orang yang memiliki kemampuan untuk membaca bintang dilangit dalam menentukan musim tanam di masyarakat. Tipologi kearifan lokal ini berdampak pada 'Sistem tanam yang mengacu pada kondisi alam'. Sistem penentuan musim tanam berdasarkan perhitungan sistem kalender musim tanam lokal masih berlaku sampai sekarang, dan dalam prakteknya juga diakui keberadaannya oleh Dinas Pertanian Kabupaten Gorontalo. ${ }^{28}$

\footnotetext{
${ }^{28}$ Salah satu bentuk kearifan lokal dan tradisi leluhur masyarakat Gorontalo yang masih dilaksanakan sampai sekarang adalah kalau menjelang musim tanam adalah menunggu perhitungan para 'Panggoba', yaitu tokoh adat yang memiliki kemampuan dalam bidang astronomi pertanian. Bahkan dalam program sektor pertanian khususnya untuk penentuan musim panen Dinas pertanian juga mempertimbangkan saran dan masukan dari para panggoba. Sistem yang dilakukan oleh Dinas pertanian dan instansi terkait lainnya, adalah diawali dengan musyawarah penentuan musim tanam tingkat kecamatan yang dihadiri pihak muspika kecamatan dan para panggoba dari utusan desa-desa yang berada pada wilayah kecamatan tersebut. Setelah musyawarah tingkat kecamatan selesai maka akan dilaksanakan musyawarah tingkat kabupaten yang dihadiri para panggoba perwakilan kecamatan di lingkungan Kabupaten Gorontalo. Sepengetahuan kami dijajaran Dinas Pertanian, perhitungan yang dilakukan oleh para 'Panggoba' sejalan dengan prediksi dan data-data iklim yang dimiliki oleh
}

Kedelapan, kearifan lokal dalam bentuk perhitungan hari baik berdasarkan 'Lowena' dan 'Kalisuwo'. Tradisi masyarakat Molamahu dan sekitarnya apabila akan melakukan suatu aktivitas berdasarkan perhitungan hari baik. Kebiasaan ini dikenal dengan konsep 'Lowena' dan 'Kalisuwo'. Secara harfiah Lowena diartikan sebagai hari kosong, sedangkan Kalisuwo diartikan sebagi kelesuan. Perhitungan hari baik ini dimaksudkan agar apa yang dilakukan masyarakat akan membawa hasil yang baik. Tipologi kearifan lokal ini oleh masyarakat dianggap sebagai pedoman dari leluhur, sehingga masyarakat ketika merencanakan sesuatu kegiatan, seperti mulai menanam ataupun aktivitas lainnya akan selalu mengacu pada aturan adat tersebut. Dampak dari bentuk kearifan lokal ini adalah munculnya ketahanan sosial masyarakat dalam bentuk 'tersedianya aturan lokal yang terkait dengan pelestarian lingkungan budaya'.

Kesembilan, kearifan lokal dalam bentuk semboyan "Tooutonu opilmulo lo bongo suburu teto mali pomolowalo binte sababu binte mali suburu olo." Artinya dimana ada pohon kelapa subur, maka disekitarnya akan ditanam jagung karena akan subur juga. Semboyan ini melahirkan kearifan lokal dalam pola sistem tanaman tumpangsari antar pohon kelapa dengan jagung. Tradisi masyarakat Molamahu ketika ladang belum ada tanaman kerasnya akan ditanami pohon kelapa dengan pola tumpangsari dengan jagung. Tipologi kearifan lokal ini berdampak pada munculnya ketahanan sosial dalam bentuk, Tumbuhnya sistem tumpangsari tanaman kelapa dengan tanaman jagung'.

Kantor Badan Metrologi dan Geofisika (BMG), walaupun sistem kerjanya berbeda, namun hasilnya seringkali sejalan. Kondisi demikian yang membuat para 'panggoba' tetap mendapatkan tempat dalam tradisi penentuan musim tanam. Informasi lebih lanjut dapat di baca pada laporan penelitian kompetitif 2009 (amir fadhilah \& Badri yatim, 2009). 


\section{Penutup}

Kearifan lokal mewujud dalam kebiasaan-kebiasaan masyarakat (kasus Komunitas Molamahu) yang memiliki pemahaman yang sama mengenai sesuatu baik dalam bentuk material maupun nilai/gagasan. Bentuk-bentuk kearifan lokal Komunitas Molamahu, antara lain mencakup : pertama, Sistem berladang budidaya jagung, memakan Ba'alo binti (beras jagung), tradisi Jaowali mobisala, ritual Molotabu, tradisi mutiayu, tradisi taliwola to hulipo (tradisi menyimpan sebagian hasil panen), sistem kalender musim tanam lokal. Kedua, Perhitungan hari baik berdasarkan 'Lowena' dan 'Kalisuwo' serta Semboyan : “...Tooutonu opilmulo lo bongo suburu teto mali pomolowalo binte sababu binte mali suburu olo.." yang mendorong lahirnya pola tanaman tumpangsari tanaman kelapa dengan tanaman jagung.

Bentuk-bentuk kearifan lokal tersebut pada dasarnya dapat dikategorikan dalam wujud sistem pertanian lokal, teknik produksi pangan lokal, motif produksi pangan lokal, pola pengolahan dan penyimpanan sumber pangan lokal, serta nilai-nilai/gagasan pangan berbasis lokal berperan dalam membentuk ketahanan sosial, yang mencakup : (1) Masyarakat memiliki kemandirian pangan, tidak tergantung kepada satu komoditas pangan, (2) Menumbuhkan partisipasi aktif masyarakat dalam penganekaragaman sumber pangan yang tidak tergantung pada beras, (3) Masyarakat terbuka terhadap perubahan, namun tidak menghilangkan tradisi sendiri. (4) Terpeliharanya relasi social melalui acara-acara adat.

Peran dan fungsi kearifan lokal dalam membentuk budaya pangan dan ketahanan pangan lokal t, antara lain mencakup : (1). Dalam aspek aksesibilitas pangan, meliputi : (a). Mempermudah masyarakat menjangkau sumber pangan, karena berorientasi pada sumber pangan lokal. (b). Meningkatkan aksesibilitas masyarakat terhadap sumber pangan Lokal.
(2). Dalam aspek ketersediaan pangan, mencakup : (a). Terpenuhinya ketersediaan pangan masyarakat karena bertumpu pada model produksi sendiri yang berbasis pada sumber pangan lokal. (b). Meningkatkan hubungan produksi antara anggota masyarakat dalam proses pengadaan pangan yang berbasis pangan local.. (3). Dalam aspek Keamanan dan kualitas pangan, meliputi : (a). Menjamin pangan aman dari bahan-bahan kimia yang membahayakan manusia. (b). Menumbuhkan kepercayaan masyarakat terhadap pangan lokal lokal yang aman dikonsumsi. (4). Dalam aspek kesinambungan pangan, mencakup : (a). Menjamin ketercukupan pangan untuk masa yang akan datang dengan berpijak pada kemandirian pengolahan pangan lokal. (b). Menjamin keberlanjutan pangan.

\section{Daftar Pustaka}

Amir Fadhilah \& Badri Yatim, 2009, Kearifan Lokal Sebagai Modal Sosial Ketahanan Pangan Masyarakat : Studi Kasus pada Masyarakat Kp. Cireundeu KeLurahan Leuwi Gajah Kecamatan Cimahi Selatan Kota Cimahi Provinsi Jawa Barat, Desa Molamahu Kecamatan Pulubala Kabupaten Gorontalo Provinsi Gorontalo , Komunitas Baduy Desa Kenekes Kecamatan Leuwidamar Kabupaten Lebak Provinsi Banten (Laporan Penelitian Kompetitif 2009), Jakarta, Lembaga Penelitian UIN Syarif Hidayatullah Jakarta

Arif Budi W., 2008, Apek Budaya pada Tradisi Kuliner Tradsional di Kota Malang sebagai Identitas Budaya : Sebuah Tinjauan Folklore, Malang : Lembaga Penelitian Universitas Muhammadiyah Malang

Foster, George $\mathrm{M}$ dan Barbara Gallatin Anderson. 1986. Antropologi Kesehatan. Penerjemah Priyanti Pakan Suryadarma dan Meutia F. Hatta Swasono, Jakarta: UI Press 
Irmayanti Meliono Budianto, 2004, Dimensi

Etis Terhadap Budaya Makan dan Dampaknya pada Masyarakat, Jurnal Makara sosial Humaniora, Vol. 8 No. 2, Agustus 2004, Fakultas Ilmu Pengetahuan Budaya UI

Keraf, A. Sonny, 2002, Etika Lingkungan, Penerbit Buku Kompas, Jakarta

Krisnamurthi Bayu, 2005, Perum Bulog Dan Kebijakan Pangan Indonesia: Kendaraan Tanpa Tujuan?, http://www.ekonomirakyat.org/edisi _19/artikel_2.htm, diakses pada tanggal 15 Desember 2005

Martaja, 2005, Solidaritas Nasional Ketahanan Pangan, http://www.sinarharapan.co.id/berita/0 510/26/opi02.html. Diakses tanggal 26 Oktober 2005

Salim, H.P., 2004. Indikator Penentu, Karakteristik, Dan Kelembagaan Jaringan Deteksi DiniTentang Kerawanan Pangan. Icaserd Working Paper No. 46. No. Dok.058.46.04.04. Pusat Penelitian dan Pengembangan Sosial Ekonomi Pertanian Jl. A. Yani No. 70 Bogor 16161

Sediaoetama AD., 1999, Imu Gizi untuk Mahasiswa dan Profesi Jilid II. Jakarta : Dian Rakyat

Setiono K., 2002, Pengembangan Psikologi Indigenous di Indonesia, dalam Jurnal Ilmiah Psikologi 'Kognisi' UMS Volume 6, Nomor 2 Nopember 2002

Suhardjo. 1989. Sosio Budaya Gizi. Departemen Pendidikan dan Kebudayaan, Direktorat Jenderal Pendidikan Tinggi, dan Pusat Antar Universitas Pangan dan Gizi IPB, Bogor

Suryana, A. 2001.Tantangan dan Kebijakan Ketahanan Pangan. Makalah disampaikan pada Seminar Nasional Pemberdayaan Masyarakat untuk Mencapai Ketahanan Pangan dan
Pemulihan Ekonomi. Departemen Pertanian. Jakarta 29 Maret. 2001

Sternberg, R.J. 2001. Why Schools Teach for Wisdom : The Balance Theory of Wisdom in Educational Settings. Educational Psychologyst. 36 (4), 227-245

Wahida Y. Mapandin, 2006, Hubungan Faktor-faktor Sosial Budaya dengan Konsumsi Makanan Pokok Rumah Tangga pada Masyarakat di Kecamatan Waena, Kabupaten Jayawijaya, Tesis pada Magister Gizi Masyarakat Program Pascasarjana Universitas Diponegoro Semarang

Witoro, 2003, Menemukan kembali dan Memperkuat Sistem Pangan Lokal, Makalah Lokakarya Forum Pendamping Petani Regio Gedepahala, Kampung Pending, Sukabum, 2-37 September 2003

Zulyani Hidayah, 2010, Rasa dan Keanekaragaman Citra Rasa Nusantara, Makalah dalam Sarasehan Nasional Antropologi 2010 'Rejinvensi Antropologi Indonesia di Era Demokrasi dan Globalisasi, Cisarua Bogor 21 - 23 Juli 2010 
